\title{
Pintér Roberta
}

\section{Drogprevenció a védett szerveknél Elemző-értékelő esettanulmány a katasztrófavédelem állományában előfordult kábítószerkereskedelmi tevékenység többrétü vizsgálatával}

\author{
The issue of drug prevention in law enforcement agencies \\ Analytical-evaluation case study with a multi-level analysis of drug \\ trafficking activity among the disaster management staff members
}

\begin{abstract}
Absztrakt
A tanulmány a katasztrófavédelem hivatásos állományában megjelenő kábítószerfogyasztási és kábítószerkereskedelmi tevékenység jelenségét és lehetséges okait mutatja be egy, a Nemzeti Védelmi Szolgálat munkája során előfordult eset kapcsán, továbbá tárgyalja a megelőzés lehetőségeit, jogszabályi környezetét és a jelenleg is kihívást jelentő kérdéseket, valamint szemlélteti a Magyar Honvédség jó gyakorlatát. A tanulmány hangsúlyos eleme annak a folyamatnak a bemutatása, ahogyan a jelenség begyürüzik a hivatásos állomány fiatal tagjai közé, továbbá a személyes motívumok feltárása. Az esettanulmány ismerteti a kábítószer-kereskedelem tárgyában elítélt volt hivatásos tiszt önreflexióját, amely az eset kapcsán benne felmerülö, a büntetöjogi következményeken túlmutató, etikai, lelkiismereti dilemmáiról, tanulságairól szól. A tanulmány vizsgálja az ügy felderítésétől kezdődő szakaszt a büntetőeljáráson át egészen az elítélést követő szakaszig, mind jogi, mind emberi oldalról és bemutatja, a büntetőeljárás hatásait után egy szervezet, valamint az elítélt volt tüzoltó életére. Mindehhez a Nemzeti Védelmi Szolgálat által tett feljelentés és annak nyomán lefolytatott, jogerős ítéletekkel lezárt büntető ügy, valamint az elkövetővel készített mélyinterjú szolgáltat alapot. A tanulmány rávilágít arra, hogy problémakör éppúgy érintheti a Nemzeti Védelmi Szolgálat további védett állománycsoportjait, mint a jelen esetben feldolgozott katasztrófavédelmi szervet.
\end{abstract}


Kulcsszavak: drogprevenció, Nemzeti Védelmi Szolgálat, katasztrófavédelem, kábítószer-kereskedelem, kábítószer-fogyasztás, esettanulmány, elemzés, statisztika

\begin{abstract}
The study presents the phenomenon and possible causes of drug use and drug trafficking among staff members of the disaster management in connection with a case that occurred during the work of the National Protective Service, as well as the possibilities of prevention, the legal environment and current challenges, and further illustrates the good practice of the Hungarian Armed Forces. The study emphasizes the process by which the phenomenon spreads among the young members of the professional staff, as well as the exploration of personal motives. One of the values of the case study is the self-reflection of the former officer convicted in drug trafficking on his ethical and conscientious dilemmas and lessons that raised in connection with the case, going beyond the criminal consequences. The study examines the effects from the investigation through the criminal procedure to the post-conviction phase, from both a legal and a human point of view, showing what happens after the criminal proceedings in the life of an organization and of the convicted former officer. All this is based on the report made by the National Protective Service and the criminal case concluded with final convictions, as well as an in-depth interview with the perpetrator. The study highlights that the problem may affect other protected bodies of the National Protective Service just like the disaster management body processed in the present case.
\end{abstract}

Keywords: drug prevention, National Protective Service, disaster management, drug trafficking, drug use, case study, analysis, statistics

\title{
Bevezetés
}

A Nemzeti Védelmi Szolgálat 2015-ben szembesült egy olyan generációs és társadalmi probléma jelenlétével a védett állományon belül, mely azelőtt nem volt jellemző, sőt kimondhatjuk, hogy a katasztrófavédelem berkein belül a kábítószer-kereskedelemre ezidáig nem volt példa. Éppen e célból volt szükséges esettanulmány tárgyává tenni annak a tüzoltó hadnagynak az esetét, aki félretéve a szakma iránti szeretetét és tiszteletét, a könnyebb anyagi haszonszerzés végett törvénytelen útra lépett. A Nemzeti Védelmi Szolgálat védett 
szervei ${ }^{1}$ közül egy szervezet példáján keresztül mutatom be azt a problémát, mely napjainkra már a többi szervezet védett állományát is érinti.

Mit kezdhet egy szervezet a kábítószer-probléma jelenlétével? Hogyan, miként lesz valakiből kábítószer-kereskedő, illetve -fogyasztó, aki egyébként szívvel-lélekkel a szakmájának él, és a szolgálatra esküdött hüséget? Milyen lehetőségei vannak egy hierarchikus szervezetnek egy ilyen probléma feltárására, megelőzésére? Mi történik a büntetőeljárás után egy szervezet életében és mi a volt munkatárséban? A tanulmány ezekre a kérdésekre fókuszálva veszi górcső alá az esetet, de mégis széleskörüen szemlélve a körülményeket, bemutatva kutatásokat, áttekintve az együttmüködések során elért közös eredményeket, valamint felvetve a megoldásra váró jogi problémákat, a lehetséges utóintézkedéseket, megelózési lehetóségeket. Joggal merülhet fel a kérdés, hogy valóban fel vannak-e készülve a védett szervek a hasonló esetekre, és adottak-e a lehetőségeik a probléma szakszerü kezelésére, megelőzésére? Előre bocsájtandó, hogy a tanulmányban bármilyen nemü, nem hivatalos statisztikaalkotás nagyon nehéz és fenntartásokkal kezelendő a változó jogszabályok tükrében, melyek kihatnak a Nemzeti Védelmi Szolgálat tevékenységére is, továbbá a statisztikai rendszer fejlesztésével járó torzulást szintén szükséges szem elött tartani.

\section{A drogfogyasztás hazánkban mint társadalmi és generációs probléma}

Bevezetésnek pillantsunk rá a kábítószer-fogyasztás hazai helyzetképére! Megállapíthatjuk, hogy a kábítószer-fogyasztás korunk egyik egyre elterjedőbb jelensége, mely a felmérések és kutatások adatai alapján leginkább a fiatal generációt érinti. A megállapítás alapját a populációs vizsgálatok, ${ }^{2}$ azaz a felnőtt, fiatalkorú és iskoláskorú népesség körében végzett kutatások jelzőszámai, a Legfőbb Ügyészség Egységes Nyomozóhatósági és Ügyészségi Bünügyi Statisztikai Rendszerében (ENyÜBS) rögzített kábítószerekkel kapcsolatos bűncselekmények, és azok elkövetöinek jellemzőit tartalmazó adatok, valamint a Nemzeti Szakértői és Kutató Központ (URL1) által megjelentetett statisztikai adatok képezik. Az adatok elemzését a Nemzeti Drog Fókuszpont végzi. Ezek az adatok nagyban meghatározzák a hazai drogellenes politika és stratégiaalkotás fó irányait, melyet jelenleg Magyarország Nemzeti Drogellenes Stratégiája ${ }^{3}$ (2013-2020)

\footnotetext{
1 A rendőrségről szóló 1994. évi XXXIV. törvény 7. §.

2 A teljes felnőtt népességet vizsgáló, a vonatkozó nemzetközi módszertani követelményeknek minden szempontból megfelelő felmérés 2007-ben készült utoljára Magyarországon.

3 Kihirdetve a 80/2013. (X. 16.) OGY határozattal.
} 
foglal össze. A stratégia fő céljának az illegális szerhasználat csökkentését tekinti. A cél elérését széles körü prevenciós tevékenységgel, a kábítószerfüggők ellátása és kezelése terén a felépülésközpontú szemléletmód és a reintegráció megerősítésével, a kínálatcsökkentés területén bünmegelőzési és bünüldözési beavatkozások hatékonyabb alkalmazásával, valamint a terjesztői magatartások elleni szigorú fellépéssel kívánja megvalósítani. A Drog Fókuszpont 2018. évi beszámolója (URL2) szerint - melyet a Kábítószer és a Kábítószer-függöség Európai Megfigyelőközpontja ${ }^{4}$ részére készített - a 18-64 éves népességben minden tizedik, a 18-34 éves fiatal felnőtt korosztályban csaknem minden ötödik személy fogyasztott már az élete során valamilyen tiltott drogot. A fiatal felnőtt és felnőtt népességben a legtöbben marihuánát ${ }^{5}$ vagy hasist ${ }^{6}$ próbáltak, de szintén népszerüek a szintetikus kannabinoidok, ${ }^{7}$ az amfetamin ${ }^{8}$ és a dizájner stimulánsok ${ }^{9}$. Az új típusú dizájner drogok az utóbbi évtizedben elterjedt, rendkívül veszélyes és kiszámíthatatlan kábítószerek, melyek Magyarországon 2010-ben jelentek meg nagyobb mértékben föleg a szegényebb régiókban, mivel a „klasszikus” drogoknál jóval olcsóbbak. Elterjedésük oka - az alacsony ár mellett - elsősorban a könnyü hozzáférhetöség. A napi adag gyakran csupán pár száz forintba kerül, és vannak olyan települések, ahol bármelyik utcasarkon beszerezhetők. Magyarországon a legdrágább közismert drognak a kokain és a heroin minősül, ezzel meghatározva a fogyasztói kör egzisztenciális jellemzőit is. A 9. és 10. évfolyamos diákok (14-18 éves) körében végzett felmérés

4 A Kábítószer és Kábítószer-függőség Európai Megfigyelöközpontja (European Monitoring Centre for Drugs and Drug Addiction, EMCDDA) tényszerü, tárgyilagos, megbízható és európai szinten összehasonlítható információkat hivatott szolgáltatni az Európai Uniónak és tagállamainak a kábítószerekkel és a kábítószer-függőséggel, valamint ezek következményeivel kapcsolatban. Célja, hogy tényekkel alátámasztott adatokkal informálja a politikai döntéshozókat és irányt mutasson a kábítószer elleni intézkedésekhez.

5 Marihuána, más néven kannabisz, mely a kendernövény szárított, megtermékenyítetlen kendervirágzata. Fő pszichoaktív összetevője a tetrahidrokannabinol (THC).

6 A hasis a női kendernövény mirigyei által termelt gyantájából készült, a marihuánánál erősebb kábítószer. Jellemzően dohánnyal keverve, cigarettában, pipában fogyasztják.

7 Szintetikus kannabinoidok, olyan vegyületek csoportja, melyet folyékony formában tetszölegesen választott szárított növény töretére rásprézve vagy felitatva szintetikus marihuánaként forgalomba hozható, és hatása azzal megegyezik. A vegyületekkel átitatott növényi töretet füstképzéssel elégetik, majd a füstöt beszívják.

8 Az amfetamin mesterségesen előállított (alfa-metil-feniletilamin nevű) szerves vegyület, hosszú ideig ható (7-13 óra) stimuláló, élénkítő hatású, vizeletből kimutatható kábítószerként ismert. Elsősorban erősebb hatású származékait (metamfetamin, LSD, Extasy) használják, kristályos, porszerủ tablettásítható anyagként.

9 A dizájner stimulánsok/drogok a 2000-es évek közepe tájékán jelentek meg az első ilyen típusú kiszámíthatatlan kábítószerek, melyeket főként tiltólistás szerek hatóanyagainak kémiai megváltoztatásával hoztak létre. Az így létrejött szerek hatásukban rendkívül hasonlítottak az illegális szerekhez, de kémiai összetételük más volt, ezért legálisnak számítottak (herbál, biofü, kati, mefedron, kristály, kréta). Általában fehér por formájában kaphatók, melyet vagy feloldva dohányra csepegtetve, kiszáradást követően cigarettába tekerve fogyasztják, vagy por, illetve tabletta formájában szedik, felszívják. 
adatai szerint közel minden tizedik diák fogyasztott már marihuánát, míg az amfetaminok fogyasztása az elmúlt négy év alatt közel ötven százalékkal nőtt. Az érettségit adó iskolatípusokban jelentősen alacsonyabbak a fogyasztási adatok, mint a szakmunkásképzők és szakiskolák tanulói körében. A megyeszékhelyeken és más városokban, illetve a falun és tanyán élőkhöz képest határozottan erőteljesebb a Budapesten lakók kábítószer-érintettsége. Bár az Országos Kriminológiai Intézet (OKRI) munkatársa, Ritter Ildikó az általa készített „A büntetési gyakorlat szigorodása a kábitószer-kereskedelem esetében" tárgyú kutatásban ${ }^{10}$ említi (Ritter, 2019), hogy míg korábban 2007 és 2011 közötti adatok alapján a kábítószer-probléma nagyvárosi jelenség volt, jelenleg már a kisebb településeken is egyre elterjedtebb. A bünügyi statisztikában regisztrált kábítószer-büncselekmények harmadát észlelik Budapesten. A 2014 és 2017 közötti hatósági észlelések adatai alapján a kábítószer-büncselekmények száma 65007000 között mozog évente, és a bíróság elé került ügyek száma egyre inkább növekszik (Ritter, 2019).

A kábítószer-függőség lehetséges okait kutatva a Nemzeti Drogellenes Stratégia kiemeli, hogy a családi viszonyok, a családi „,védőburok” sérülése, a közösségek életét meghatározó értékek, valamint az írott és íratlan normák gyengülése, megsértése elvezet oda, hogy az ifjúság körében, majd később a fiatal felnőtt és felnőtt korban is mind gyakoribb a megküzdési képességek, a döntéshozó készségek és a pozitív jövőkép hiánya. A pszichoaktív szerek a teljesítményt, kitartást igénylő örömök helyett azonnali közérzetjavulással, feszültségcsökkenéssel kecsegtetnek. Tulajdonképpen ,instant boldogságot” jelentenek.

\section{A stresszfaktor és a drogfogyasztás a védett szervek hivatásos állományban}

Áttekintve a társadalmi és bűnügyi adatokat, ezeket kivetítve a közszolgálatot teljesítő, alapvetően stresszes feladatokat ellátó hivatásos állományra, természetszerü és egyben érthető, hogy a probléma begyürüzött a védett szervek életébe is. Egyrészt, ha a 18-34 év közötti korosztályban minden ötödik személy érintett, akkor ez a számarány az új felszerelő fiatal állományt mindenképpen érintheti. Másrészt, ezt a megállapítást támasztják alá a Nemzeti Védelmi Szolgálat kábítószerrel kapcsolatos felderített büncselekményeinek

10 A vizsgálat tárgyát a kínálati oldali kábítószer-büncselekmény miatt indult eljárások alkották, azaz azok az eljárások, amelyek kábítószer-termesztés, előállítás, országba történő behozatal, kivitel, illetve az ország területén történő átvitel, továbbá, forgalomba hozatal, kereskedelem miatt indultak, üzletszerüen vagy bünszervezetben és/vagy jelentős mennyiségü kábítószerre valósultak meg. 
statisztikái is. A Nemzeti Védelmi Szolgálat saját 2011-2019 évre vonatkozó adataiból nyomon követhető, hogy átlagosan évente hét hivatásos személy vonatkozásában készül feljelentés kábítószerrel kapcsolatos büncselekmény elkövetése miatt, tehát vagy fogyasztó ( $\mathrm{kb}$. négy) vagy kereskedő (kb. három), és velük 2-10 polgári személy (átlagosan négy) áll kapcsolatban, akik szintén érintettek a kábítószerrel kapcsolatos büncselekményben. Összevetve az országos adatokkal - miszerint minden tizedik felnőtt, illetve a 18-34 év közötti korosztályban minden ötödik személy fogyasztott már valamilyen típusú kábítószert - statisztikailag még mindig elenyésző a védett szervekre eső esetszám. Bár ez jelezheti azt is, hogy a magasabb társadalmi elvárások elé állított közszolgálat egyértelmüen szabálykövető magatartással jár együtt, ellenben nem feledkezhetünk meg a látenciában maradt esetekről sem. Ez utóbbi lehetőséget egy durva és semmi esetre sem hiteles becslés is alátámaszthatja, miszerint például ha a rendőrség dolgozóinak száma megközelítőleg 38000 fó és ebből - a statisztikai átlagot alapul véve - minden tizedik ember fogyasztott már kábítószert, akkor valóban nagy a látencia. A kábítószer-fogyasztás ellen hat, hogy a hivatásos állomány köreibe csak kifogástalan életvitellel rendelkező személyek kerülhetnek és maradhatnak. Annak a lehetősége azonban továbbra is fennáll, hogy ők életük során fogyasztottak már kábítószert, kipróbálhatták, de nem váltak szenvedélybeteggé, függővé. Kérdésként merülhet fel, hogy a felvételi eljárás vagy a hivatásos szolgálati viszony fennállása során az éves orvosi vizsgálatok alatt szürik-e az állományt kábítószer-fogyasztás tekintetében (a szúrópróbaszerü ellenőrzés esetét nem említve). Ez a kérdés eléggé összetett, azonban megjegyezhető, hogy a Nemzeti Védelmi Szolgálat Humánigazgatási Főosztály Egészségügyi és Pszichológiai Alosztályának tájékoztatása szerint a válasz mindhárom esetben: nem, ezért sajnos szükséges a látencia lehetőségével is számolnunk.

A felderítési statisztikai adatokból megállapítható, hogy az egyenruhás, tiszthelyettes állomány érintett leginkább a kábítószer-büncselekmények elkövetésében. Kiemelkedik a kábítószer-fogyasztás mint elkövetési magatartás, ugyanakkor szaporodik azon esetek száma is, amikor az állomány a fogyasztás mellett a kábítószer-terjesztésében is részt vesz. Mivel az érintett hivatásos személyek a kábítószer megszerzése alkalmával az érintett bünözői csoportokkal, személyekkel is kapcsolatba kerülnek, akár zsarolhatóvá válnak. Megtörtént az is, hogy az érintett hivatásos személyek nem pénzzel fizettek a kábítószerért, hanem hivatali helyzetükkel visszaélve az általuk hozzáférhető nyilvántartások adatait adták ki a kábítószer-terjesztőknek. A Nemzeti Védelmi Szolgálat saját kábítószer-büncselekményekre vonatkozó 2011-2019 évi statisztika adatai szerint a védett állománycsoportokból a rendőrség, a katasztrófavédelem, 
a Nemzeti Adó- és Vámhivatal, illetve a büntetés-végrehajtás érintett. Ez utóbbi esetben a fogvatartottak részéről érkező igény és kereslet generálhatja a kábítószer-kereskedelmet folytatható hivatásos személyek számát. A többi három állománycsoportot illetően a kábítószer-fogyasztás hátterében akár a stratégia által is említett megküzdési képességek, a döntéshozó készségek és a pozitív jövőkép hiánya is állhat, mely mindenképpen összefügg a stressz kezelésével, levezetésével. A katasztrófavédelem részéről nyilatkozó pszichológus szakmai tapasztalatai szerint az állomány tekintetében a probléma jelenlétére két lehetséges válasz adható a korcsoport függvényében.

Negyven éves kor alatt a fiatalok várják az izgalmas helyzeteket, riasztásokat, hiszen tapasztalatszerzés, segítségnyújtás és kaland miatt érkeztek a szakmába. Amikor érkezik egy riasztás feldobódnak, megindul az adrenalin, az izgatottság, elkezdődik a mentés folyamata, maga a feladatellátás, és megszületnek az életre szóló sztorik. Csak egy-egy komolyabb eset után bontakozik ki a szakma igazi kihívása, az esetleg szörnyü tragédiák és látott események lelki kezelése. Az idő előrehaladtával viszont ezek az élmények egymásra rakódnak és már komoly szorongást okozhatnak. Az állandó ugrásra kész, készenléti állapot kimeríti a szervezetet. Az ezzel való megküzdésben fontos szerepe van a családnak. Ha otthon a családi életben minden rendben van, akkor könnyebb a feldolgozás, jobban megy mindezek kezelése. Ha viszont ez nem így van, akkor az illető egy másik megküzdési módot kénytelen választani, mely adott esetben sajnos lehet a kábítószer- vagy alkoholfogyasztás is.

Ezek alapján feltételezhető az is, hogy a fiatalok a riasztások, az izgalmas helyzetek átélésének hiánya miatt, szinte az unalom ellenszereként nyúlhatnak az illegális szerekhez, mert hiányzik az a pörgés, ami riasztáskor, mentéskor éri őket. Vagy esetleg azért fogyasztják, hogy bátorságot merítsenek a kábítószerekből. Ezzel szemben az idősebb korosztály, negyven év felett már a szorongás kezelése, levezetése miatt alkalmazhatja a kábítószert, mert esetükben nem ritka, hogy a csengő megszólalása a gyomor összerándulását okozza. Mindkét csoportnál megeshet, hogy azért nyúl az illegális szerekhez, mert nincs már biztos családi háttere, vagy éppen kiemelkedően szükséges teljesíteni a szolgálatok alatt, félretéve a másodállások okozta fáradtságot. Bár ez utóbbi korcsoportra nem is igen jellemző a feszültség ilyen módú oldása.

A pszichológus és a nyilatkozó tűzoltó kollégák egyöntetü véleménye szerint a (szolgálati) csoportnak hatalmas támogató és megtartó ereje van. Egy-egy eset után megbeszélik mi történt, kibeszélhetik érzéseiket, kiventillálhatják magukból a látottakat, tapasztaltakat, amire a további szorongás megelőzése miatt nagy szükség is van, azonban az évek előrehaladtával egyre nehezebbé válik a feldolgozás. Az Országos Katasztrófavédelmi Főigazgatóság Humán 
Szolgálatának a korcsoportokra és a riasztásokra vonatkozó tájékoztatása szerint 2019-ben 40 éves kor alatt 2671 fö látott el készenléti szolgálatot, míg 40 év felett 2294 fö. Kerületi szinten évente átlagosan majdnem 1300 riasztás történik, ez naponta átlagosan 3-4 alkalmat jelent, együtt értve a tüzoltási és mentési feladatokat. Természetesen az állomány tagjainak leterheltségét és a stresszel való megküzdés megfelelő módjának feltérképezését a rendszeres alkalmassági vizsgálatok keretében elvégzett tesztek és a vizsgálatokat lezáró beszélgetések biztosítják. A pszichés egyensúly megállapítása érdekében a vizsgálatok során a szorongás, a pszichoszomatizációra való hajlam, a frusztrációs tolerancia és a devianciák meglétének vizsgálata elsődleges szerepet kap. A katasztrófavédelem állománya részére a váltásokon belüli kollegiális beszélgetéseken túl a pszichológus kollégához, szakemberhez fordulás lehetősége is biztosítva van, természetesen önkéntes alapon. Intézményesített stresszkezelés azonban nincs, autogén tréningek megtartására alig van kapacitás, drogprevenciós előadás vagy életvezetési mentálhigiénés foglalkozások nincsenek. Amit a pszichológus, mint szakember javasolni tud mindenkinek, az a hobbi. Mindenkinek kell egy dolog, tevékenység, amit szívesen csinál, amiben örömét leli és kikapcsolódik, levezeti a stresszt. Kifejezetten segít a pszichés egyensúly megtartásában és kiégés esetén is.

A Nemzeti Védelmi Szolgálat statisztikájából kiragadva a kábítószerrel kereskedő tűzoltó hadnagy esetét, és meghallgatva az állomány pszichológusát, a lehetséges stresszkezelésen túl a kábítószer-büncselekmény felé való fordulás további motivációs okait vizsgálva egy újabb, nem meglepő indok bukkant fel: a pénz. A katasztrófavédelem pszichológusával folytatott beszélgetésből kiderült, hogy az Y generáció szülötteinek (1980-2000), az úgynevezett ezredfordulós nemzedéknek már magasabb a feszültségi szintje, a modern technika korába, egy „felpörgött” világba és a fogyasztói társadalomba születtek bele, mindez generálhatja a kalandvágyat, az adrenalinéhséget. De az Y generáció további jellemzőit tekintve a célok gyors elérését elősegítő eszközök alkalmazása sem meglepő, még ha ezek illegálisak is. Ennek a generációnak számos tagja végignézte, szülei hogyan küzdötték fel magukat a társadalmi ranglétrán, hogyan mentek mindebben tönkre egészségileg, és bomlottak fel házasságaik, majd váltak később mégis kiszolgáltatottá a munkaerőpiacon. Ezért ennek tanulságát levonva, ők már nem hajlandóak erre. Így az Y generáció némely tagja számára nem maradt biztos, megtartó családi háttér, csak a rohanó, felszínes kapcsolatok, példává vált a mindent felülíró anyagi javak fontossága, a több lábon állás, a gyors haszonszerzés, illetve a külvilágnak élés. Mindezzel a büncselekménybe sodródás, azaz a kriminalizálódás veszélye növekedett meg. 
Ritter Ildikó kutatásában egy korábbi tanulmánya megállapításait is felidézi, melyben a kábítószer-büncselekmények elkövetőit az akkor vizsgált ügyek ${ }^{11}$ alapján csoportokba osztva jellemzi (Ritter, 2019). A vizsgált kínálati oldali kábítószer-büncselekmények, vagyis 457 elemzett eset 49\%-a kereskedelem, illetve fogalomba hozatal, és mindössze 4,6\%-át követik el bünszervezetben. Az elkövetők átlagéletkora 36 év. Az egy eljárásra jutó elkövetők száma átlagosan négy fö, és háromnegyedük magyar. Iskolázottság tekintetében ez az elkövetői kör jelentősen eltért az elkövetői átlagtól. Nem volt olyan elkövető, aki legalább az általános iskolát ne fejezte volna be. Az érettségivel rendelkezők aránya $27 \%$, az egyetemet, föiskolát végzetteké $6 \%$ volt. Szakmunkásképzőt, szakiskolát 43\%-uk végzett. Megdöbbentő eredményt mutatott a mintába került elkövetők legális munkatevékenységhez és legális jövedelemszerzéshez való viszonya, ugyanis 53\%-uk rendelkezett legális munkaviszonnyal és jövedelemmel. Ez pedig azt jelzi, hogy egyrészt a hazai hatóságok előtt ismertté vált kínálati oldali kábítószer-büncselekményt elkövetők többsége nem a hagyományos bünözői szubkultúrából kerül ki, másrészt pedig azt, hogy alapvetően igazodnak a többségi társadalmi normákhoz és értékekhez, azaz fontos számukra, hogy valamilyen szinten kapcsolódjanak a normakövető állampolgárokhoz. Ezt erősíti, hogy a mintába kerültek több mint fele volt büntetlen elóéletü. Az ismertté vált, felderített kínálati kábítószer-büncselekményt elkövetők többsége az alsó szintü hálózathoz tartozott. Gyakorlatilag középszintnél feljebb nem jutott a vizsgált időszakban a hazai bünüldözés. Jellemzően futárok, kannabisz-ültetvényt létrehozók, illetve ott dolgozók, valamint dílerek ${ }^{12}$ (27\%) képezték az ismertté vált elkövetői kört. Ez alapján négy csoport vált elkülöníthetővé.

1) Az első csoport a szegénység elől menekülők csoportja, átlagéletkoruk 42 év, nem kábítószerfüggők, büntetlen előéletüek, jellemzően futárok, kannabisz-ültetvényen dolgozók vagy olyan ,alkalmi vállalkozók”, akik nem rendelkeznek állandó felvevő piaccal. Itt található a legtöbb női elkövető.

2) A második csoport az elkövetőknek egy olyan része, mely egyéb illegális tevékenységből váltott át a kábítószer-büncselekményekre, leginkább kereskedelemre vagy féllegális üzletetekre. Köztük már több a rendszeres

11 A vizsgálat tárgyát a kínálati oldali kábítószer-büncselekmény miatt 2007-2011 között indult eljárások alkották, azaz azok az eljárások, amelyek kábítószer-termesztés, előállítás, országba történő behozatal, kivitel, illetve az ország területén történő átvitel, továbbá forgalomba hozatal, kereskedelem miatt indultak, üzletszerüen vagy bünszervezetben és/vagy jelentős mennyiségü kábítószerre valósultak meg. Mindösszesen 457 esetet vizsgált a tanulmány.

12 Dílerek azok a kábítószert forgalomba hozó vagy azzal kereskedő személyek, akik maguk is több-kevesebb gyakorisággal fogyasztanak kábítószert, és tevékenységük célja a haszonszerzésen túl, hogy a másoknak eladott kábítószerből fedezzék saját szükségletüket is. 
fogyasztó és a büntetett előéletü. Átlagéletkoruk 36 év. Komoly felső szintủ befektetők ellen - a mintába került ügyek között - nem folyt eljárás.

3) A harmadik csoportot a dealerek alkották, akik mástól vették meg az árut, számos esetben a fővárosban, majd vidékre szállították eladásra. Közülük sokan maguk is használtak kábítószert, sőt voltak köztük kábítószer-problémával küzdők is. Többségüknek volt kialakított felvevő piaca, azaz megvolt a fogyasztói köre. A csoportot leginkább az alsó középosztályhoz tartozó személyek alkották. Az elkövetők jellemzően 22-35 év közöttiek voltak, átlagéletkoruk 31 év volt, 42\%-uk legalább középfokú végzettséggel rendelkezett, de volt több felsőfokú végzettségü elkövető is. Fő jövedelemforrásuk nemcsak ez a tevékenység volt, $61 \%$-uk rendelkezett legális munkahellyel és/vagy tanult valahol. A lebukásuk oka jellemzően, hogy drogtevékenységük vagy egyre elörehaladottabb volt és/vagy több sikeres üzletet követően egyre magabiztosabbakká és óvatlanabbakká váltak.

4) A negyedik csoportot a középszintü kereskedők képviselték. Ök voltak a legkevesebben, az elkövetők 10\%-át alkották. Nem voltak kábítószerfüggők, de többen alkalmi szerhasználónak bizonyultak. Az elsőben, illetve ebben a csoportban volt a legtöbb külföldi elkövetö.

A vizsgált esetekben az elkövetés tárgya a leggyakrabban a marihuána volt, ezt követték az amfetaminok, a kokain, majd pedig a metamfetaminok. Az esetek több, mint 80\%-ában az elkövetőktől több kábítószertípus került lefoglalásra. A harmadik csoportot jellemző tényezők akár konkrétan a tűzoltó hadnagyról és társairól is íródhattak volna, átlagéletkorukat, iskolázottságukat, legális jövedelemforráshoz való kötöttségüket, de mégis állandó illegális kábítószer fogyasztói piacukat tekintve. A fentiek alapján a dílerhálózat jellemzően az Y generáció tagjaiból állt, mint ahogyan a fogyasztói kör is. Az ügyben ismertté vált büntetlen elöéletủ dílerek fő célja elsősorban az anyagi haszonszerzés volt, így lassan eljutottak oda, hogy hivatásos munkájuk az illegális tevékenységük fedőfoglalkozásává vált.

\section{Az esettanulmány}

A Nemzeti Védelmi Szolgálathoz 2015-ben több forrásból érkezett információ egy kokaint áruló tüzoltóról. Hatáskörüket és a jogi minősítést megalapozta, hogy az érintett a kábítószerkereskedelmi tevékenységet a szolgálati helyén, szolgálati idejében is folytatta. Az öttől tíz évig terjedő szabadságvesztéssel büntetendő büncselekmény gyanújának megállapításához és a tevékenység bizonyításához különféle erő, eszköz és módszer együttes és egyidejü alkalmazására 
volt szükség, több szervvel közösen együttmüködve. A Nemzeti Védelmi Szolgálat hatáskörét tekintve jellemzően korrupciós és hivatali büncselekmények felderítésére hivatott szerv. Ez esetben a kábítószer-kereskedők életviteléhez igazodó figyelések és akciók megkívánták a szervezet alkalmazkodóképességét, rugalmasságát, nem beszélve az éjszakai találkozók és kábítószerátadások megfelelő minőségü, bizonyításra alkalmas rögzítéséről, mely szakszerü, speciális eszközparkot, kreativitást igényelt. A felderítés eredményeképpen ismertté vált események alapján megállapítható volt, hogy az érintett tüzoltó kábítószerkereskedelmi tevékenysége során rendszeresen szolgálati idejében, szolgálati helyére vagy annak közvetlen közelébe hívta fogyasztóit, és adta át a kábító hatású szereket. Tevékenységét szabadidejében különböző szórakozóhelyeken folytatta. Akadályoztatása esetén egy taxisofőrrel szállíttatta ki a kért kábítószert a megfelelő címre, aki ezért a fuvardíjon felül némi jutalékot kapott, illetve a nála lévő kiporciózott adagokat felárral maga értékesítette. A taxisofőrön túl a tüzoltó további négy terjesztővel is dolgozott, illetve két felsőbb dílertől szerezte be a különböző típusú drogokat. Tevékenysége Budapesten kívül - egy díler segítségével - vidékre is kiterjedt. Nyilvánvalóvá vált, hogy két tüzoltó kollégája is tudott a tevékenységéről, sőt, segítette őt, illetve vásárolt is tőle saját fogyasztásra is, mert alkalomszerüen mindannyian fogyasztottak kábítószert.

A megfigyelések és lehallgatások eredményei után a három ismertté vált tüzoltó, két felső díler és hat alsó terjesztő, illetve a taxis futár ellen bünszövetkezetben elkövetett kábítószer-kereskedelem tárgyában élt feljelentéssel a Nemzeti Védelmi Szolgálat, valamint kábítószer birtoklása tárgyában több tucat kábítószert fogyasztó személyt illetően tett feljelentést. Az illetékes ügyészség felkérésére a feljelentés bizonyítékain túl a büntetőeljárásban szükséges volt a tevékenység rendszerességének és az árult illegális szer kábítószer voltának megállapítása. Az ismertté vált több mint fél éves tevékenység során árult marihuánával, hasissal, különféle tablettákkal és kokainnal való rendszeres kereskedést minden kétséget kizáróan szükséges volt igazolni.

Fedett nyomozó alkalmazása révén, igazságügyi vegyészszakértő bevonásával, több alkalommal, összesen majdnem 50 gramm kokain vásárlása útján bizonyításra került a rendszeres, szolgálati időben és szolgálati helyen végzett kábítószerkereskedelmi, illetve haszonszerzési tevékenység. Az elfogás során összehangolt akciók és házkutatások lefolytatásának koordinálását a Nemzeti Védelmi Szolgálat végezte. A teljes müveletben részt vettek az Országos Katasztrófavédelmi Főigazgatóság Ellenőrzési Szolgálatának munkatársai, a Nemzetközi Bünügyi Együttmüködési Központ munkatársai, az akkori Központi Nyomozó Föügyészség Budapesti Regionális Osztálya és háttértámogatóként a Nemzetbiztonsági Szakszolgálat. A szolgálati helyen elrendelt ellenőrzés alatt 
kábítószerkereső kutyák járták be a területet, több helyszínen azonos időben megindultak a házkutatások. A tüzoltó hadnagy közvetlenül 10 gramm kokain eladása után egyenruhában került elfogásra a szolgálati helyén, szolgálati idejében. További két kollégáját, felső kapcsolatát és terjesztő társait szintén elfogták, a házkutatások során kokaint, marihuánát, különféle - többnyire Extasy - tablettákat foglaltak le.

A nyomozás metodikáját illetően az eljáró föügyészségi katonai ügyész kiemelt figyelmet fordított a fedett nyomozó szakszerü tevékenységére. Az eljárás során ügyelni kellett arra, hogy a fedett nyomozó tevékenysége ne terjedjen túl az elkövető ismert kereskedelmi tevékenységén, vagyis ne legyen provokatív és ne hajszolja súlyosabb büncselekménybe az elkövetőt azon túl, amit már eddig is megvalósított. A fedett nyomozó tevékenysége csupán az eddig elkövetett büncselekmény bizonyítására szolgálhat. A büntetőeljárás folyamán bizonyítékok egész sora igazolta a bünszövetségben történő kábítószer-kereskedelem büntettét, a napra, órára, percre pontosan felsorolt cselekményeket. Ezek ismeretében, beismerő vallomások nyomán az akkor hatályban lévő tárgyalásról lemondás jogintézményét választotta az összes elkövető, megelőzve ezzel egy több évig elhúzódó eljárási procedúrát. (Ritter Ildikó kutatásából megtudhatjuk a vádtól az ítéletig átlagosan két év telik el, amikor a kiszabott büntetés már nem is feltétlenül tölti be rendeltetését és visszatartó erejét.) Az eljárás felgyorsításán túl nyilvánvaló, hogy a beismerés kedvezőbb büntetési tételt is eredményezett. Az eljáró ügyész hangsúlyozta, hogy ezt a jogintézményt, melyet az új büntetőeljárásról szóló 2017. évi XC. törvény az egyezség ${ }^{13}$ jogintézményével váltott fel, csak akkor célszerü alkalmazni, ha minden elkövető beismerésben van, különben sértheti az eljárás érdekeit és veszélyezteti a bizonyítást.

\section{Az ítéletek}

Ritter Ildikó kutatásában közölt, 2017. évi statisztikai adatokon alapuló vizsgálat szerint a kínálatoldali kábítószer-büncselekményeknél az egy ügyre jutó szabadságvesztés-büntetés átlagolt időtartama 4 év 2 hónap volt. A két véglet szerint a legrövidebb 5 hónap a leghosszabb 13 év. A vizsgált esetben az említett tüzoltók a tárgyalásról lemondás nyomán kábítószer-kereskedelem tárgyában kiszabott ítéletükben - egy kivételével - letöltendő szabadságvesztést, valamint közügyektől eltiltást és pénzbüntetést kaptak. A tüzoltó hadnagy 4 év és 8 hónap börtönbüntetése fele részének kitöltése után jó magaviselettel feltételes

13 A büntetőeljárásról szóló 2017.évi XC. törvény LXV. fejezet 407-411. §. 
szabadságra bocsátható. Továbbá várt rá 5 év közügyektől eltiltás, 280000 forint pénzbüntetés, valamint majdnem 5,5 millió forint összegü vagyonelkobzás a bűncselekményből szerzett vagyonra vonatkozóan. Ez utóbbit az eljárás ismert adati alapján számította ki az ügyészség, ugyanis a beismerỏ vallomásban elmondottak szerint a kokain grammját 14000 forintért vásárolta, majd 16 000-18 000 forintért adta tovább. Az Extasy tablettát 700-1000 forintért vásárolta, majd 1000-1500 forintért értékesítette. A Speed grammjának beszerzési ára 1700-2000 forint volt, mely 2500 forintért kelt el általában, a marihuána és hasis 2000 forintos beszerzéssel 2500 és 2700 forintért került értékesítésre. Összevetve ezt a Drog Fókuszpont 2015. évi adataival (Csesztregi et al., 2015), az eset hủen tükrözi a piac diktálta árakat.

A tủzoltó hadnagy a több mint fél éves kábítószerkereskedelmi tevékenysége alatt csak az ismertté vált napi cselekmények következtében majdnem 5,5 millió forint illegális bevételre tett szert, mely később a vagyonelkobzás tárgyát képezte. Azonosított beszerzési forrását szintén 4 év 8 hónap letöltendö börtön fokozatú szabadságvesztésre ítélték, a további terjesztőkre átlagosan 2 év 3 hónap börtönbüntetést szabtak ki. Az egyik tüzoltó tiszthelyettes tettestárs szintén ugyanennyit kapott, míg a másik kollégája 1 év 3 hónap szabadságvesztést 3 évre felfüggesztve. Ezeknek a súlyos vádaknak, illetve későbbi ítéleteknek a katasztrófavédelem állományában szinte semmi nyilvánvaló előjele nem volt. Parancsnoki kezdeményezésre a munkaviszonyuk alatt kifogástalan életvitel ellenőrzést egyikükkel szemben sem folytattak le az esetet megelözően. Pszichológiailag alkalmasnak minősültek mindhárman, egészségügyi alkalmassági vizsgálatuk megfelelő volt. Sőt, a tüzoltó hadnagy a HUNOR mentőcsapat tagja volt, mely a katasztrófavédelem egy központi, speciális helyzetekben bevethető hivatásos, nehéz kutató-mentő mentőszervezete. A csapat alkalmas a bekövetkezett veszélyhelyzetek, katasztrófák során jelentkező speciális mentési feladatok ellátására, az elsőként beavatkozók megerősítésére, és külföldön Magyarország hivatalos katasztrófavédelmi mentőcsapataként végzi tevékenységét. Munkahelyén mentor is volt, többször dicséretben részesült, fenyítve sohasem volt. Vajon mi visz rá egy ilyen elhivatott szakembert minderre? Hol veszett el az integritás és hol kezdődött az erkölcsi lejtő?

\section{A belesodródás folyamata}

Kutatásom során meghallgattam az érintett hadnagy parancsnokát, kollégáit, és ők egyöntetüen állították, hogy kiváló képességü, intelligens, megbízható, közösségi embernek ismerték meg a gyakran helyszíni parancsnokként gyakorlati 
tevékenységben aktívan résztvevő kollégájukat. Egyszóval megbíztak benne. Érdekes, hogy - őket idézve - egyfajta árulásként élték meg a tettét, megfogalmazásuk szerint sérült a tüzoltói becsület. A szervezeti kultúrát tekintve kiemelhető, hogy az ilyen életmódot folytató embereket kiveti magából a közösség, elítéli a tevékenységet egy közös, nemcsak jogszabály alapú, hanem morális értékrend mentén. A megkérdezett kollégák elmondták, hogy semmi kézzelfogható jelét nem látták az egyébként kiválóságként elismert tüzoltó hadnagy káros szenvedélyének vagy illegális tevékenységének. Életviteléről annyi volt mindenki számára ismert, hogy az életvidám, társaságkedvelő vezéregyéniség, rengeteget bulizott, az utóbbi időben már hétköznap is. Mindenki ismerte számtalan, hölgyekhez és átbulizott estékhez kötődő sztoriját, hedonista életmódját. Többször észrevették, hogy fáradtabb, de más gyanús körülményre nem lettek figyelmesek. Talán egy eset kelthetett volna némi gyanút, amikor egyik kollégája több pénzt, maximum hatvanezer forintnyi összeget vett észre a pénztárcájában véletlenül. Viszont a közterületi rendör járőrökre vonatkozó szabályozással ellentétben ilyen összeg maguknál tartása a szolgálatos tüzoltók körében nem korlátozott, hiszen teljesen más feladatokat látnak el, ezért a korlátozás szükségtelen és indokolatlan lenne. Bármilyen hétköznapi okból kifolyólag természetesen lehet valakinél ennyi készpénz, mégis volt, aki úgy fogalmazott: „Amikor jöttek, tudtam, hogy öt viszik el!’. A katasztrófavédelem pszichológusa elmondta, a hadnagy elfogását (2016) megelőző mindkét évben pszichológiai vizsgálaton esett át, tekintettel arra, hogy 2014-ben a kötelező alkalmassági vizsgálat meghosszabbítására került sor, majd pedig vezetői pozícióba kerülése és hadnagyi kinevezése alkalmával 2015-ben ismét szükségessé vált a vizsgálat. Az eredmény mindkét esetben kiegyensúlyozott személyiségképet mutatott. Kifejezetten előnyös személyiségjegyekkel, mint például a fegyelmezettség, pontosság, maximalizmus, szabálykövető magatartás, teljesítmény és folyamatos tanulás iránti igény, jó irányító és szervezőkészség. Bár két évvel az elfogása elött családi körülményeiben több változás is bekövetkezett. Egy évvel később parancsnokká válhatott, noha akkor már javában illegális tevékenységet folytatott. A gyanúsítotti vallomással összevetve anyagi nehézségei jelentkezésével egyidőben, vagy azt követően kezdhetett bele a kábítószer-kereskedelembe. A gyanúsított kihallgatásai alkalmával és a Fővárosi Törvényszék Katonai Tanácsa által megtartott ülésen a volt hadnagy nyilatkozataiban elmondta, majdnem tíz éve teljesített hivatásos tüzoltói szolgálatot, bejárta a ranglétrát, szakirányú főiskolai végzettséggel vezetői beosztásba került, fizetése akkor volt a legmagasabb, szolgálati lakásban élt és vagyonát egy tízéves autó képezte. Másodállása már nem volt. Édesanyját - szükség szerint - anyagilag támogatnia kellett. Elmondta, hogy 2015-ben sokat járt szórakozni, a bulik alkalmával találkozott a kábítószerrel, alkalmanként fogyasztotta is, de 
soha nem vált függővé. A szórakozásai nagyon költségesek voltak, így a drogot árulni kezdte, melyből finanszírozni tudta a bulikat és anyagi problémái is enyhültek, viszont a keresett illegális jövedelem java részét felélte. Vevői köre a szórakozóhelyeken épült ki, majd egyre bővült. A büntetőeljárásban tettét azonnal beismerte, így a tárgyalásról lemondás jogintézményével a számára kapható legkedvezőbb ítélet született, 4 év 8 hó börtönbüntetés, melynek fele kitöltése után feltételesen szabadlábra kerülhetett. Négy hónapot töltött előzetes letartóztatásban.

Ritter Ildikó kutatásában rámutatott, hogy a cselekmény súlyához igazodó büntetés akkor éri el a célját, ha minél közelebb van időben az elkövetés időpontjához (Ritter, 2019). Ilyen esetben a tanulmányban megkérdezett elkövetők a büntetést megérdemelt büntetésnek tekintik, elfogadják, és jellemzően jó magaviselet miatt a lehető legkorábban szabadulnak. A zárt intézetben töltött időt igyekeznek produktívan eltölteni, az elkövetett cselekményt, korábbi magatartásukat felülvizsgálják és új életcélokkal, normakövető viselkedéssel felvértezve szabadulnak. Az elkövetők által elfogadott, megérdemeltnek tekintett büntetés mértéke - a vonatkozó vizsgálat eredményei szerint - 2-3 előzetes letartóztatásban és/vagy jogerős ítélettel börtönben összesen eltöltött év volt. Ez elégséges ahhoz, hogy a büntetés célját elérje, az elkövető számára szenvedéssel járó, büntetés értékü, de elfogadható legyen, a lehető legkevésbé sújtsa az elkövető családját, érvényesülhessen a generál- és speciálprevenciós büntetési cél, illetve ne okozzon a büntetés nagyobb kárt az államnak, mint maga a büntetendő cselekedet. Ennyi idő alatt az elkövető szociális kapcsolatai még többségében megmaradnak, de a családtól való elszigetelődés, a cellatársakkal és a börtönkörnyezetben eltöltött idő pedig teljes mértékben motiváló hatással bír a törvénytisztelő magatartás betartására és a bünismétléstől való távolmaradásra. Az ettől hosszabb tartamú szabadságvesztés több kárt okozhat, mint amennyi elönnyel kecsegtet. Az elkövető kinti szociális hálója megbomlik, a börtönártalmak kihatnak a személyiségre, az igazságszolgáltatás elleni ellenszenv provokatív magatartást eredményezhet, az igazságosságról alkotott kép megdőlésével a normakövető viselkedés elveszti értékjellegét, amely újabb büncselekmény elkövetését eredményezheti. Fentiek azokra az elkövetőkre vonatkoznak, akik a bekerüléskor az átlag elkövetőktől magasabb társadalmi státuszúak és iskolázottabbak voltak, másrészt nem voltak kábítószerfüggők vagy a szerfüggőségük még nem volt előrehaladott. Jelen esetben mindez a büntetések mértékére és a várható prevenciós hatására is igaz lehet. A hivatásos tüzoltók beismerték és vallomásaikban kijelentve megbánták tettüket. Azon túl, hogy a beismerő vallomás a tárgyalásról lemondás jogintézményének alkalmazását is szolgálta, a folytatólagos gyanúsított kihallgatási jegyzőkönyvek tanulsága szerint a tüzoltó 
hadnagy előzetes letartóztatása megszüntetése után és börtönbe vonulása előtt önkéntes alapon a Drog Stop Budapest Egyesület drogprevenciós programjában is közremüködött, illetve a börtönben töltött időtartamot valóban produktívan töltötte, drogprevenciós előadásokat tartott. Elmondása szerint szándékában állt a drog veszélyeit megismertetni másokkal, saját esetén keresztül bemutatva a problémát, illetve azt, hogy milyen következményekkel járhat, ezzel is bizonyítva őszinte megbánását. Munkatársai beszámoltak továbbá arról, hogy a szervezet éves csapatépítő tréningjén rövid látogatása alkalmával kollégái előtt személyesen elnézést kért mindenkitől, magától a szakmától és hivatástól, mert szégyent hozott rá. Kijelentette, az az ő legnagyobb büntetése, hogy már soha többé nem lehet tüzoltó. Bizonyára volt kollégái számára ez sokat jelentett, hiszen az elfogás alkalmával jelen lévő szolgálatos vétlen állomány az elmondások alapján olyat élt át, amit soha nem fog elfelejteni: „A hirtelen jött próbariasztás és központi ellenörzés, kiabáló és rendre utasitó fegyveres rendörök, a kábítószerkeresö kutyák, az elfogott munkatársak, majd jött a csend..."

\section{Az utóintézkedések}

Az elfogás után az érintett tüzoltóegység állománya, átélt egy traumát és - a pszichológus szavaival élve - gyászolt három kollégát, akit számukra nem ismert okból elvesztett. Az állományhoz még aznap este kirendelt szakpszichológus elmondása szerint a kollégák csak ültek egy asztalnál és nem tudtak megszólalni, néztek maguk elé. Majd az információ morzsákból közösen megpróbálták a történetet összerakni, az elejtett szavakból és a kábítószerkereső kutya jelenlétéből, mert részükre senki nem adott akkor tájékoztatást. Az esetet követően a Nemzeti Védelmi Szolgálat több alkalommal tartott preventív jellegü előadást a történtekről a Fővárosi Katasztrófavédelmi Igazgatóság valamenynyi tüzoltó parancsnokságán vezetői szinten, hangsúlyozva a vezetői felelösség és a parancsnoki gondoskodás fontosságát. Az igazgatóság tájékoztatása szerint szolgálatparancsnoki, tüzoltásvezetői továbbképzéseken, illetve a kibővített kirendeltségvezetői értekezleten is feldolgozták az esetet, kiemelve a kábítószer-használat egészségügyi, büntetőjogi és munkajogi következményeit. A vezetői beosztást betöltő személyek részére szervezett képzéseken különös figyelmet fordítanak a beosztottakkal való helyes bánásmódra, a viselkedési jegyek értékelésére és az esetlegesen felmerült problémák helyi kezelése mellett, a szakember általi segítségnyújtás lehetőségének ismertetésére. A közvetlenül érintett katasztrófavédelmi állomány néhány munkatársa interjúja során egyöntetűen hiányolta a későbbi tájékoztatás elmaradását, esetleges 
drogprevenciós előadás megtartását. Kérdésként merült fel bennük, hogy miről ismerjék fel a drogfogyasztás jeleit, mit kellett volna ilyen esetben tenni mint parancsnok vagy mint bajtárs. A kábítószer-fogyasztással kapcsolatos ismeretek nem tartoznak a szakterületükbe, nem ismerik az árulkodó jeleit, nem látják a szürés lehetőségét úgy, mint az alkoholos befolyásoltság kérdésében. A probléma jelenlétét elfogadva és a megelőzést támogatva egyöntetü igény mutatkozott drogprevenciós előadások megtartására. Hangsúlyozták, hogy ez a tudás magánéletük során is hasznos lenne, hiszen sokaknak kamaszkorú gyermeke van. Az igény jelzése okán a Nemzeti Bünmegelőzési Tanács drogprevenciós munkatársa elmondta, hogy ez idáig a hivatásos állomány részére belső drogprevenciós előadások nem készültek, de minden szakanyag rendelkezésre áll a hiánypótló előadások elkészítéséhez. Az ORFK Bünmegelőzési Osztályának munkatársa szintén megerősítette, hogy az állomány irányában drogprevenciós előadásokat nem tartanak, az előadások célcsoportját leginkább a civil fiatalkorúak képezik, mivel a hivatásos szolgálatot teljesítők esetében zéró tolerancia érvényesül a kábítószerekkel kapcsolatban, és egyértelmü, hogy ezt be is tartják azok, akik maguk is a törvény örei. Mégis a Nemzeti Védelmi Szolgálat tapasztalatait és statisztikai adatait alapul véve kétségek ébredhetnek a hivatásos állomány tagjainak kábítószer-fogyasztást elutasító magatartását illetően. Jóllehet zéró tolerancia érvényesül a korrupcióval, az alkoholfogyasztással kapcsolatban, mégis szervezetünk létrejöttének indokai közé tartozik ezen elvek betartásának/betartatásának érvényesítése. A vezetők eszköztárát a teljesség igénye nélkül vizsgálva felmerült a kérdés: mit tehet a parancsnok és milyen jogi következmények lehetségesek a kábítószer-fogyasztás megelözése érdekében?

\section{Jogi kérdések és lehetőségek}

Az eset kapcsán megvalósított (jog)szabálymódosítások közé tartozik a katasztrófavédelmi objektumokba való ki-belépés szabályainak megszigorítása, valamint a vezetői beosztásba való kinevezést és a rendfokozatban történő soron kívüli elöléptetést megelőzően a Nemzeti Védelmi Szolgálat előzetes véleményalkotási eljárásának ${ }^{14}$ bevezetése.

14 A rendőrség belső bünmegelőzési és bünfelderítési feladatokat ellátó szerve kijelöléséről, valamint feladatai ellátásának, a kifogástalan életvitel ellenőrzés és a megbízhatósági vizsgálat részletes szabályainak megállapításáról szóló 293/2010. (XII. 22.) Korm. rendelet a vezetői beosztásba kinevezés és a rendfokozatban történő soron kívüli előléptetést megelőző előzetes véleményalkotásra vonatkozóan új rendelkezésekkel (13/B-D. §) egészült ki. 
Felmerült olyan szabályozási igény is, melynek kapcsán a jogszabályok alkalmazásának alapos vizsgálata és az esetleges jogszabálymódosítási lehetőségek több egyeztetést kívánnak. A könnyebb áttekinthetőség érdekében a kábítószer-fogyasztással kapcsolatos ellenőrzési kérdéseket három részre érdemes bontani:

- az állományba kerülés elötti;

- a már állományban lévő hivatásos szolgálatot teljesítők rendszeres, valamint

- a szúrópróbaszerü szürés lehetőségeire.

Az állományba kerülést megelőző prevenciós lehetőség körébe a kifogástalan életvitel ellenörzése, ${ }^{15}$ illetve a pszichológiai és orvosi alkalmassági vizsgálatok tartoznak, mely során a jelentkező kábítószer-fogyasztásra vonatkozó komplex szürésen mehetne át, illetve a környezettanulmány elkészítése során lakókörnyezetét és családi körülményeit erre figyelemmel is vizsgálnák. Viszont jelenleg a hivatásos szolgálatra jelentkezők esetében végzett kábítószer-fogyasztásra vonatkozó felvételi eljárás során alkalmazott előszürés a védett szerveket illetően szervenként eltérő lehet. Sőt, a jelentkezők nagy részét az alkalmasságot szabályzó norma szerint nem érinti, mert a rendvédelmi szerveknél csak a speciális szolgálati beosztásba jelentkezőknél, vagyis az „S” kategóriába tartozóknál kell az egészségi alkalmassági vizsgálatnak kiterjednie a kábítószer-fogyasztás kizárására, ${ }^{16}$ ennek érdekében a vizeletgyorsteszttel történő vizsgálatára. A hivatkozott rendelet szerint az egészségügyi alkalmassági vizsgálatnak csak indokolt esetben kell kiterjednie az alkohol-, gyógyszer-, kábítószer-fogyasztás, valamint függőség esetleges jeleinek megállapítására. ${ }^{17}$ Bizonyára a kérdéskör védett szervenkénti részletes vizsgálata szükséges lenne, de ez sajnos meghaladja jelen tanulmány kereteit.

A jelentkezők mellett a hivatásos állományban lévők esetében is szükségszerü több figyelmet fordítani a folyamatos szürésre annak megelőzése céljából, hogy ne válhasson a hivatásos állomány tagja észrevétlenül kábítószer-fogyasztóvá. Jelenleg az évenként teljesített orvosi alkalmassági vizsgálatok a kábítószer-fogyasztásának szürésére a legtöbb állománycsoportban nem terjednek ki. A hivatásos szolgálati viszony tartama alatt alkalmazható szúrópróbaszerü ellenőrzés lehetőségét az Országos Katasztrófavédelmi Főigazgatóság és a Nemzeti

15 A rendvédelmi feladatokat ellátó szervek hivatásos állományának szolgálati jogviszonyáról szóló 2015. évi XLII. törvény (Hszt.) 42. § (1) bekezdése és a 293/2010. (XII. 22.) Korm. rendelet 7. §-a.

16 57/2009. (X. 30.) IRM-ÖM-PTNM együttes rendelet egyes rendvédelmi szervek hivatásos állományú tagjai egészségi, pszichikai és fizikai alkalmasságáról, közalkalmazottai és köztisztviselői munkaköri egészségi alkalmasságáról, a szolgálat-, illetve keresőképtelenség megállapításáról, valamint az egészségügyi alapellátásról 29. § (4) bekezdése szerint

17 57/2009. (X. 30.) IRM-ÖM-PTNM együttes rendelet 6. § (2) bek. h) pont. 
Védelmi Szolgálat közös utóintézkedése alkalmával vizsgálta. A szúrópróbaszerü ellenőrzés a hivatásos szolgálati viszony alatt támadhatatlan alapot jelenthetne a további intézkedések elrendelésére. Ennek viszont jogi keretei jelenleg nem állnak rendelkezésre, ezért érthető módon az ellenőrzésnek sincs kialakult gyakorlata sem a katasztrófavédelmi szervnél, sem a további védett szerveknél. Az ORFK Humánigazgatási Szolgálat, Egészségügyi Szakirányító és Hatósági Főosztály szakmai álláspontja szerint nagyon fontosak az állományt érintő drogprevenciós intézkedések, amelyre a fiatal generáció szolgálatba lépésével egyre nagyobb hangsúlyt fektetnek. Kockázatként említhető, hogy jelenleg a kábítószer-fogyasztás vonatkozásában szürés nem történik sem a felvételizők, sem a már hivatásos szolgálatot teljesítők esetében, kivéve, ha a szolgálatra alkalmas állapotot kizáró, nyilvánvaló jelek észlelhetők. A Hszt. 102. § (1) bekezdés $h$ ) pontja értelmében a hivatásos állomány tagja a szolgálat ellátásával összefüggésben köteles a szolgálatképes állapot megállapítása érdekében a befolyásoltság kiszürése céljából az alkohol, a kábítószer vagy pszichotrop anyag fogyasztásának ellenőrzését célzó, mütétnek nem minősülő vizsgálatnak magát alávetni a miniszteri rendeletben ${ }^{18}$ meghatározottak szerint.

E hivatkozott miniszteri rendelet (továbbiakban: BM rendelet) hatálya az általános rendvédelmi feladatokat ellátó szervre, az idegenrendészeti szervre, a belső bủnmegelőzési és bủnfelderítési feladatokat ellátó szervre, a terrorizmust elhárító szervre, a hivatásos katasztrófavédelmi szervre és a büntetés-végrehajtási szervezetre, valamint a polgári nemzetbiztonsági szolgálatokra terjed ki. A BM rendelet szerint a kábítószeres befolyásoltság ellenőrzéséhez három feltétel ${ }^{19}$ a biológiai mintavételt megalapozó körülmény - szükséges:

5) ha a kábítószer okozta bódult állapotra jellemző testi és pszichikai tünetek észlelhetők;

6) ha az egyes kábítószerek fogyasztása okozta elvonási tünetek észlelhetők;

7) vagy a hivatásos állomány tagja a kimutatható időn belüli kábítószer-fogyasztásról nyilatkozik.

A fenti három feltételt és a kábítószer-fogyasztás okozta befolyásoltság gyanúját erősíti, ha az érintettnél vagy közvetlen környezetében kábítószer gyanúját keltő anyag, vagy fogyasztáshoz szükséges eszköz, tárgy található, illetve - például - az érintetten tüszúrások nyomai fedezhetők fel.

18 22/2015. (VI. 15.) BM rendelet a belügyminiszter irányítása alá tartozó rendvédelmi feladatokat ellátó szervek hivatásos állományú tagjainak szolgálatképes állapota megállapítása érdekében a befolyásoltság kiszürése céljából elvégezhető vizsgálatok köréről és a vizsgálat végrehajtásának szabályairól.

19 22/2015. (VI. 15.) BM rendelet 6. pontja - A kábítószer-fogyasztás okozta befolyásoltság vizsgálata során a biológiai mintavételt megalapozó körülmények 7. §. 
Maradva esettanulmányunk tárgyánál, az érintett katasztrófavédelmi egység parancsnoka szúrópróbaszerü kábítószerrel kapcsolatos ellenőrzést csak fogyasztási vagy elvonási tünetek észlelése, vagy az érintett kolléga önbevallása esetén rendelhetett volna el a szolgálatra alkalmas állapot ellenőrzése érdekében. Így teljesen érthető a drogprevenciós tájékoztatásra vonatkozó igény az érintett szervek részéröl annak érdekében, hogy lehetőségük legyen a tünetek felismerésére és a témában való nagyobb jártasság elsajátítására. Az említett BM rendelet tárgyalja a biológiai mintavétel végrehajtásának ${ }^{20}$ menetét is. Amennyiben az állomány hivatásos tagjának kábítószer-fogyasztás okozta befolyásoltsága feltételezhetö a testi és pszichológiai tünetek alapján, úgy vér- és vizeletmintavételre kell intézkedni, egyéb esetben csak vizeletvétel szükséges. A mintavételt az alapellátó vagy az ügyeletes orvos végzi a szolgálati elöljáró jelenlétében, az emberi méltóságot tiszteletben tartva. A BM rendelet két esetben elöszürés elvégzését is elöírja, amennyiben rendelkezésre áll a nyálmintavételre, vagy a vizeletminta előszürésére alkalmas rendszeresített eszköz. De az előszürés is csak a kábítószeres befolyásoltság gyanújának, tehát a három feltétel legalább egyikének fennállása esetén alkalmazható. Mindez azért elgondolkodtató, mert az alkoholos befolyásoltság mérését gyakorlatilag szúrópróba-szerüen lehet elvégezni a szolgálatteljesítésre alkalmas állapot ellenőrzése céljából. A kábítószer-fogyasztás már önmagában is bármikor büncselekménynek minősül, mégis a szúrópróbaszerủ ellenőrzése külön feltételekhez kötött. Ezzel szemben az alkohol fogyasztása szolgálaton kívül teljesen legális. E logika mentén haladva azt gondolnánk, hogy amit a törvény szigorúbban rendel büntetni, azt szigorúbban is kell ellenőrizni.

Az éles lőfegyverrel ellátott szolgálat vagy a mentési feladatok végrehajtása önmagában is hatalmas felelősséget ró a szolgálatot teljesítőkre, hiszen adott esetben emberi élet, testi épség forog kockán. Éppen ezért a szolgálatra alkalmas állapot biztosítására és ellenőrzésére kiemelt figyelmet lenne szükséges fordítani. Továbbá a védett állomány körében elkövetett kábítószerrel kapcsolatos büncselekmények büntetőjogba ütköző mivoltukon kívül a fokozott társadalmi elvárások elé állított közszolgálati szervek negatív társadalmi megítéléséhez és a közbizalom megrendüléséhez vezethetnek. A tapasztalat azt mutatja, a parancsnokok nem merik felvállalni az ellenőrzés végrehajtását, mivel nem ismerik a különböző kábítószerek fogyasztásának tüneteit. Mint láthattuk, a pszichológiai tesztek nem feltétlenül képesek előre jelezni a problémát, vagy a probléma nem tủnik olyan súlyosnak, hogy a pszichológusnak jelzéssel

20 22/2015. (VI. 15.) BM rendelet 7. pontja - A kábítószer-fogyasztás okozta befolyásoltság vizsgálata során a biológiai mintavétel végrehajtásáról 8 . §. 
kellene élnie. Amennyiben mégis az életvitelt érintően felmerülnek olyan jelek, melyek a tévútra tévedést jelezhetik, szükséges lehet azt mielőbb tisztázni. Így elsődlegesen a parancsnoki személyes elbeszélgetés vagy figyelemfelhívás is preventív hatással bírhat. Továbbiakban, ha bármilyen aggodalomra alapot adó jel tapasztalható az életvitelben, akkor a parancsnoki kezdeményezésre induló kifogástalan életvitel ellenőrzés ${ }^{21}$ jogintézménye feltárhatja a problémát. Konkrét információ esetén a Nemzeti Védelmi Szolgálat felé történő jelzés alapján kifogástalan életvitel ellenőrzése, illetve akár felderítés megindítása kezdeményezhető a büncselekmény gyanújának megerősítésére vagy kizárására. Súlyosabb esetben a tett intézkedések feltárhatják az életvitel hivatásra nézve kockázatos voltát, esetlegesen fényt deríthetnek indokolatlan vagyongyarapodásra is. A kábítószer-kereskedelem kapcsán a vagyonban bekövetkezett indokolatlan változás esetén az úgynevezett „vagyongyarapodási vizsgálat” sajnos a hatályos jogszabályok szerint csak ezzel egyidejü hivatalos büntetőeljárás megindításával, vagyis feljelentés megtételével kezdeményezhető a Nemzeti Adó- és Vámhivatalnál. Az eljárások további munkajogi kérdéseket vethetnek fel, például a szolgálati jogviszony folyamatossága tekintetében, melynek vizsgálata meghaladja jelen esettanulmány kereteit. Fentiekkel összhangban a katasztrófavédelem az esettel kapcsolatos szakmai nyilatkozatában kifejtette, hogy a BM rendelet az alkoholos befolyásoltság ellenőrzésével ellentétben nem tartalmaz olyan rendelkezést, amely lehetőséget adna a kábítószer okozta befolyásoltság szúrópróbaszerü ellenőrzésére. Az ellenőrzésre csak az említett tünetek fennállása esetén van lehetőség, ezért minden más esethez a rendelet módosítására lenne szükség. 2018-ban két alkalommal is sor került az Országos Katasztrófavédelmi Főigazgatóság és az Nemzeti Védelmi Szolgálat között szakmai egyeztetésre a témában, melyen az Országos Katasztrófavédelmi Főigazgatóság vezető főorvosa, a fegyelmi szakterület képviselője is részt vett, s ennek eredményeként úttörő módon közösen a hatályos belügyi szabályozás módosítását javasolták. A katasztrófavédelem a rendelet módosítása esetére is kifejezte aggályát a végrehajthatóságot illetően, mert az alkalmazható drogtesztek csak meghatározott típusú kábítószerek fogyasztásának felfedésére alkalmasak, a szintetikus, új típusú divatdrogok kimutatására nem.

21 A rendvédelmi feladatokat ellátó szervek hivatásos állományának szolgálati jogviszonyáról szóló 2015. évi XLII. törvény (Hszt.) 42.§ (1) bekezdésében és 293/2010. (XII. 22.) Korm. rendelet 7. §-ában foglaltak szerint. 


\section{A Magyar Honvédség jó gyakorlata}

A belügyi szabályozáson és gyakorlaton túl tekintve a Drog Fókuszpont 2018as éves jelentése a Magyar Honvédség drogprevenciós tevékenységét kifejezett jó példaként emelte ki, csak úgy. A jó gyakorlat megismerése érdekében látogatást keretében megvizsgáltam a Magyar Honvédség Egészségügyi Központjának gyakorlatát. A szervezeti tapasztalatok alapján teljes szemléletformálásra volt szükség a Magyar Honvédség szervezetén belül, melynek elősegítésére felállították a Drogprevenciós Bizottságot. ${ }^{22} \mathrm{~A}$ drogprevenciós intézkedéseket teljes vezetői támogatottsággal indították el, saját komplex megelőzési programot $^{23}$ készítve, összhangban a Nemzeti Drogellenes Startégiával. Létrehozták a hozzá kapcsolódó jogi hátteret és finanszírozást. A MH képviselői jelenleg is részt vesznek a tárcaközi Kábítószerügyi Koordinációs Bizottság tevékenységében. Az állományra vonatkozó adataikat a Drog Fókuszpont éves jelentései tartalmazzák, melynek továbbítása a Kábítószer és Kábítószer-függőség Európai Megfigyelöközpontja felé történik.

A kábítószer-fogyasztással kapcsolatos zéró tolerancia elvét több módon elősegítik:

- Ismeretátadással (értekezleten, közösségi-színtér programokon).

- MH Egészségmegőrző Program keretében.

- Prevenciós feladatokat ellátók továbbképzése révén (drogprevenciós feladatokat ellátó szakemberhálózat és kortárs kiképzők folyamatos továbbképzése).

- Katonai közép- és felsőfokú intézmények tanrendjébe épített előadásokkal.

- Missziós állomány felkészítése alkalmával megtartott előadásokkal.

- Kombinált komplex drogszürő-vizsgálati rendszer müködtetésével

- alkalmassági-vizsgálat keretében végrehajtott szürővizsgálatok: szerződéses állomány, külszolgálatra jelentkező állomány, illetve a külszolgálatból visszatérő állomány, valamint a 3 hónapnál hosszabb külföldi beiskolázásra tervezett állomány vonatkozásában;

- szolgálatteljesítésre alkalmas állapot ellenőrzése: a vizsgálatot az állományilletékes parancsnok vagy szolgálati elöljáró rendeli el szúrópróba-szerủen a fogyasztás megelőzése céljából, illetve havonta egy alkalommal a csapategészségügyi szolgálat keretében végezhető és központilag is elrendelhető a vizsgálat.

22 40/2012. (VI. 15.) HM utasítás a Magyar Honvédség Drogprevenciós Bizottságáról.

23 167/2009. (HK 5.) MH HEK intézkedés a Magyar Honvédség személyi állománya kábítószer hatása alatti állapotának, illetve kábítószer fogyasztásának vagy tartásának ellenőrzésével kapcsolatos feladatok végrehajtásáról. 
- Kábítószer-fogyasztás felderítésével.

- Kábítószer-fogyasztás azonosításával és bizonyításával.

A zéró tolerancia elvét fokozatosan vezették be. Kezdetben a fogyasztói attitüd felmérése történt meg az állomány körében, melyek válaszai alapján már látták, hogy a drogfogyasztással kapcsolatban nagy volt a tolerancia. Ez önmagában azt feltételezte, hogy az állomány fogyasztja is a kábítószert. Első lépcsőben megindultak az állományba jelentkezők szürései, amelyet a külszolgálatra indulók kötelező vizsgálata, végül a szúrópróbaszerủ ellenőrzések bevezetése követett. Az 1996-2009. évre vetített adatokból kiderült, hogy körülbelül minden ötödik sorkatona fogyasztott kábítószert, majd az is nyilvánvalóvá vált, hogy az állomány több mint 30\%-a érintett.

A szürés folyamatában egy patikai gyorsteszttel, úgynevezett „fésüs” teszt alkalmazásával előszürést végeznek és vizsgálják a vizeletet különböző kábítószer-fajtákra (például marihuána, ópiátok, amfetaminok és kokain). Amenynyiben ezek valamelyikénél pozitív eredményt mutat a gyorsteszt, azt a mintát nagylaboros müszeres vizsgálatnak vetik alá. Az előszürés, vagyis a mintavételi csomag költsége személyenként megközelítőleg 2500 forint, a laborvizsgálat 16000 forint. Az álpozitív minták lehetőségét szem elött tartva a mintavételkor jegyzőkönyv is készül az adatokon túl arra vonatkozóan is, hogy az illető mit evett, ivott vagy milyen gyógyszert szed. A szürések alapján drogtérképet állítottak fel, mely megmutatja a helyileg fogyasztott kábítószertípusokat (például Debrecen - máktea, Budapest - amfetaminok, Győr - kokain), így célzott prevenciós előadás vagy intézkedés tartható az adott szolgálati helyen. Egységes tüneteket a különböző kábítószerek összetétele és hatásfoka, tisztasága miatt nem lehet meghatározni, mint ahogyan a felszívódási időt és kimutathatóságot is befolyásolják ezek a tényezők, így ez az időtartam pár naptól több hétig is eltarthat. Az eddigi tapasztalataik alapján elmondható, hogy a kábítószer-fogyasztást illetően a rövid szolgálati idővel rendelkező, egyenruhás, altiszti, tiszthelyettesi, 30 év alatti, rendezetlen családi hátterü állomány érintett leginkább. A jelenleg hatályos szabályozás ${ }^{24}$ szerint ha valaki a szerződéses állományba jelentkezik, de a drogtesztje pozitív, három évig nem jelentkezhet újra. Már hivatásos állományba tartozás során pozitív előszürési eredmény esetén

24 A 10/2015. (VII.30.) HM rendelet a katonai szolgálatra való egészségi, pszichikai, fizikai alkalmasságról, valamint a felülvizsgálati eljárásról a foglalkozás-egészségügyi alkalmasság vizsgálat keretében végzett kábítószer-fogyasztás ellenőrzését szabályozza, továbbá a honvédelmi miniszter a Magyar Honvédség személyi állománya kábítószer hatása alatti állapotának, illetve kábítószer-fogyasztásának vagy tartásának ellenőrzéséről szóló 26/2008. (HK 7.) HM utasítása a szúrópróbaszerü ellenőrzés folyamatát szabályozza. 
az érintett munkaviszonya felfüggesztésre kerül, míg a nagylaboros vizsgálat hiteles eredményt nem ad. Amennyiben az is pozitív, úgy azonnali jelentési és fegyelmi eljárás indítási kötelezettség lép érvénybe, a szolgálati jogviszony megszüntetésre kerül. Ha az adott mintát illetően álpozitív eredmény születik, az érintett a szolgálatba visszahelyezésre kerül és minden addigi elmaradt járandóságát megkapja. Még ha szigorúnak hangzik is az eljárás, hangsúlyozandó, hogy a kábítószer-fogyasztás nemcsak büncselekménynek minősül, de jelentős nemzetbiztonsági kockázatot is jelent.

A szüréseknek a fogyasztás kialakulásának megelőzésében is kiemelkedő szerepe van, mert az állandó kontroll miatt a fogyasztás kockázata megnő, a lebukás veszélye nagy, így a várható következmények miatt a hivatásos állomány tagjai jellemzően elállnak a fogyasztástól. A szürések további haszna, hogy objektív kép alkotható a fogyasztási szokásokról, illetve az állomány esetleges bünözői csoportokkal való kapcsolattartására is következtetni lehet. A Katonai Nemzetbiztonsági Szolgálattal együttmüködve több esetet is felderítettek, melyek között a legmeglepőbb egy fiatal soför esete volt, aki csak azért szerelt fel az adott szolgálati beosztásba, hogy tökéletes fedéssel tudja szállítani a kábítószert a katonák és más civilek számára. Láthatjuk, hogy a honvédség drogprevenciós tevékenysége széleskörü, nagy múltra tekint vissza. Mind a jelentkezők esetében az alkalmassági vizsgálatok során, mind a már állományban lévők esetében megtörténik a rendszeres és szúrópróbaszerü szürés is, melyek visszatartó ereje vitathatatlan. E szüréseken túl különféle belső, a hivatásos állomány részére tartott drogprevenciós előadásokra is sor kerül.

\section{Következtetések}

A látencia ellenére is észrevehető a kábítószer-probléma jelenléte a védett szervek körében. Erre azok a kirívó esetek világítanak rá, melyeket a Nemzeti Védelmi Szolgálat munkája során felderít. A megelőzés érdekében komplex drogprevenciós előadások keretében szükséges lehet lépeseket tenni a kábítószer-használat egészségügyi, büntetőjogi és munkajogi következményeinek ismertetésére. Mint ahogyan a katasztrófavédelem állománya is jelezte, a belső drogprevenciós előadások, tájékoztatások is hasznosak lehetnének, sőt igény is mutatkozik rájuk. A szürések fontosságát és megelőző szerepét a Honvédség jó gyakorlata mutatta be és igazolta. A Nemzeti Védelmi Szolgálat hatáskörébe tartozó kifogástalan életvitel ellenőrzés és a belső bünfelderítés szintén visszatartó eröként funkcionálhat. A további prevenciós lehetöségek a jogszabályi és financiális háttér megteremtése nélkül bizonyára nem tudnak megvalósulni. Szürés 
hiányában az állományt érintő kábítószer-fogyasztásra vonatkozó felméréssel, statisztikával nem rendelkeznek a védett szervek, eltekintve az éves orvosi és felvételi alkalmával kitöltött kérdőívtől, ${ }^{25}$ melyen az érintett önként nyilatkozik a ,fogyasztott-e kábitószert, drogot" kérdést illetően. Határozott fellépés hiányában elgondolkodtató e kérdés hatékonysága vagy megelőző ereje.

\section{Felhasznált irodalom}

Csesztregi T., Horváth G. Cs., Nyírády A., Péterfi A., Port Á., Tarján A. \& Varga O. (2015). 2015 ös Éves Jelentés (2014-Es Adatok) Az EMCDDA Számára. REITOX. http://drogfokuszpont. $\mathrm{hu} / \mathrm{wp}$-content/uploads/EMCDDA_jelentes_2015.pdf

Ritter I. (2019). A büntetési gyakorlat szigorodása a kábitószer-kereskedelem esetében. Kutatási beszámoló. Országos Kriminológiai Intézet.

\section{A cikkben található online hivatkozások}

URL1: Nemzeti Szakértöi És Kutatóközpont. https://www.nszkk.gov.hu/

URL2: Drog Fókuszpont, Éves Jelentések. http://drogfokuszpont.hu/eves-jelentesek/\#2018

\section{Alkalmazott jogszabályok}

1994. évi XXXIV. törvény a Rendőrségről

2017.évi XC. törvény a büntetőeljárásról

2015. évi XLII. törvény a rendvédelmi feladatokat ellátó szervek hivatásos állományának szolgálati jogviszonyáról

293/2010. (XII. 22.) Korm. rendelet a rendőrség belső bűnmegelőzési és bünfelderítési feladatokat ellátó szerve kijelöléséröl, valamint feladatai ellátásának, a kifogástalan életvitel ellenőrzés és a megbízhatósági vizsgálat részletes szabályainak megállapításáról

10/2015. (VII. 30.) HM rendelet a katonai szolgálatra való egészségi, pszichikai, fizikai alkalmasságról, valamint a felülvizsgálati eljárásról

22/2015. (VI. 15.) BM rendelet a belügyminiszter irányítása alá tartozó rendvédelmi feladatokat ellátó szervek hivatásos állományú tagjainak szolgálatképes állapota megállapítása érdekében a befolyásoltság kiszürése céljából elvégezhető vizsgálatok köréről és a vizsgálat végrehajtásának szabályairól

25 3. melléklet az 57/2009. (X. 30.) IRM-ÖM-PTNM együttes rendelethez. 
57/2009. (X. 30.) IRM-ÖM-PTNM együttes rendelet egyes rendvédelmi szervek hivatásos állományú tagjai egészségi, pszichikai és fizikai alkalmasságáról, közalkalmazottai és köztisztviselői munkaköri egészségi alkalmasságáról, a szolgálat-, illetve keresőképtelenség megállapításáról, valamint az egészségügyi alapellátásról

80/2013. (X. 16.) OGY határozat a Nemzeti Drogellenes Stratégiáról 2013-2020

26/2008. (HK 7.) HM utasítás a honvédelmi miniszter a Magyar Honvédség személyi állománya kábítószer hatása alatti állapotának, illetve kábítószer fogyasztásának vagy tartásának ellenőrzéséről

40/2012. (VI. 15.) HM utasítás a Magyar Honvédség Drogprevenciós Bizottságáról

167/2009. (HK 5.) MH HEK intézkedés a Magyar Honvédség személyi állománya kábítószer hatása alatti állapotának, illetve kábítószer fogyasztásának vagy tartásának ellenőrzésével kapcsolatos feladatok végrehajtásáról

\section{A cikk APA szabály szerinti hivatkozása}

Pintér R. (2021). Drogprevenció a védett szerveknél. Elemző-értékelő esettanulmány a katasztrófavédelem állományában előfordult kábítószer-kereskedelmi tevékenység többrétű vizsgálatával. Belügyi Szemle, 69(11), 1995-2020. https://doi.org/10.38146/BSZ.2021.11.7 